解 説

\title{
磁場による視射角偏向機能を備えた反射型高速電子線回折 （RHEED）装置の試作と動的構造変化への応用
}

\author{
深谷 有喜*.三井 裕*. 重田 諭吉*,*1 \\ （受理1999年 9 月 2 日，掲載決定1999年12月 4 日）
}

\begin{abstract}
Development of a High-energy Electron Diffraction (RHEED) Apparatus
Equipped with a Magnetic Deflector to Change the Glancing Angle and its Application to the Study of Dynamic Structure Change

Yuki FUKAYA, Hiroshi MITSUI and Yukichi SHIGETA
\end{abstract}

(Faculty of Science \& Graduate School of Integrated Science, Yokohama City University, Seto 22-2, Kanazawa-ku, Yokohama 236-0027, Japan)

(Received September 2, 1999, Accepted December 4, 1999)

\section{1. はじめに}

原子スケールで表面の構造を観察する手法としては, 走査型トンネル顕微鏡（STM）が有力であるが，吸着 や膜成長といった動的過程を追らことは，特別な条件 ${ }^{1)}$ を除き非常に難しい。 また，表面下の層構造に関して知 りたい場合は無力に等しい。これに対し, 反射型高速電 子線回折法（RHEED）は表面の平均的な情報ではある が，表面構造に関する詳細な情報を与えてくれる．そし て，薄膜成長では，鏡面反射強度に注目すると，一層一 層の成長周期に対応した規則的な变化を示し, 薄膜成長 のモニターとして広く用いられている（RHEED振 動) ${ }^{2-6)}$. さらに, 入射電子線の試料に対する視射角 $(\theta)$ を変化させると, 表面に垂直な原子位置に関する情報が 得られ, 表面下数層までの構造を知ることができる ${ }^{7-10)}$. この視射角変化に対する回折スポットの強度変化を RHEED ロッキングカーブと呼び, 構造解析に利用され ている.

筆者らは, $\mathrm{Si}(111)$ 表面上の $\mathrm{Si}$ の初期成長過程につい

\footnotetext{
* 横浜市立大学大学院総合理学研究科（而236-0027 横浜市金沢区瀬戸 22-2)

*1 横浜市立大学理学部（广236-0027 横浜市金沢区瀬戸22-2)
}

て，RHEED 強度を成長のモニターとしてサブモノレイ ヤーで成長を止め, 成長後の表面構造をSTM 観察し, 成長過程を研究してきた ${ }^{11-14)}$ 。 その過程で, Si の成長 表面の構造が, 成長中と成長を止めた後では変化し, 異 なっていることが分かってきた ${ }^{14)}$.そこで，表面数原子 層の構造解析が可能な RHEED ロッキングカーブを成 長中の薄膜の構造解析に応用することを考えた.

従来, RHEED ロッキングカーブの測定は, 主に電子 銃や試料を機械的に動かすことによって視射角を変化さ せて行われていた ${ }^{15-18)}$. そのため測定を短時間で行らこ とは非常に難しく，成長中のその場観察は行われていな かった，筆者らは，磁場により入射電子線の視射角を素 早く変化できる偏向系を備えた RHEED 装置を作成し， Si のエピタキシャル成長に応用した ${ }^{19-20)}$ 。ここでは, 磁場偏向系を備えた RHEED 装置の概要と測定に括け るキーポイントを中心に述べ, 最後に $\mathrm{Si} / \mathrm{Si}(111)$ 薄膜成 長へ応用した結果について述べる.

\section{RHEED 装置}

\section{1 実験装置の概要}

実験装置は, RHEED システムと電子ビーム蒸着シス テムが組み込まれた超高真空装置であり ${ }^{21)}$, 図 1 に試作 した RHEED 装置の模式図を示す，超高真空装置には， 


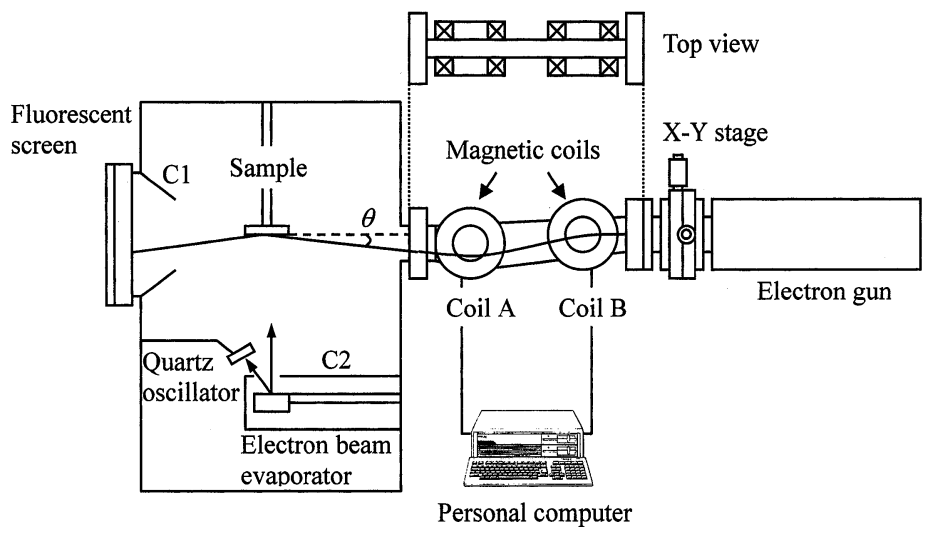

図 1 磁場偏向機能を備えた RHEED 装置の模式図.

その他に試料交換のためのロードロック室が設置されて いる. 成膜室はイオンポンプ，チタンゲッタポンプによ り排気し，到達圧力は $7 \times 10^{-8} \mathrm{~Pa}$ である。ロードロッ ク室はロータリーポンプ, ターボ分子ポンプにより排気 し, 到達圧力は $9 \times 10^{-7} \mathrm{~Pa}$ である. 図中の $\mathrm{C} 1$ と $\mathrm{C} 2$ は, 蛍光スクリーンの遮光のために作成した RHEED 用円錐状遮光パネル，和よび蒸発源用遮光パネルであ る.

\section{2 磁場による偏向装置}

成長中の RHEED ロッキングカーブを測定するため には，入射電子線の視射角を素早く変化させることが必 要である，そこで，磁場による電子線偏向系を採用し た。

偏向装置は図 2 に示すよらに，長方短管とそれを挟む 2 組のヘルムホルッコイルから成っている.コイルに流 す電流は，パーソナルコンピュータにより制御し， 2 組 のコイルの磁場を自由に変化させることができる. 電子 銃には，アパーチャが $80 \mu \mathrm{m}$ の日本真空技術侏)製のもの を使用した。また，電子ビームを偏向系の中心を通る光 軸にあわせるために, X-Y ステージが両者の間に組み 込まれている（図 1 参照).

正確な RHEED の強度解析を行うためには，入射電 子線の平行性・収束性が視射角の変化に対して保たれて いなければならない，そのため偏向系の試作には，特に 電子線の収束に注意を払い設計を行った，有限な幅を持 つ電子線を発散させることなく偏向させるためには，磁 場が均一な領域を広く取り, 磁場の無い領域との境界領 域に挌いて空間的に不均一な磁場の影響を極力減らすこ とが重要である，そのため，装置のサイズを考慮して許 される最大の径の中空コイル（内径 $70 \mathrm{~mm}$, 外径 130

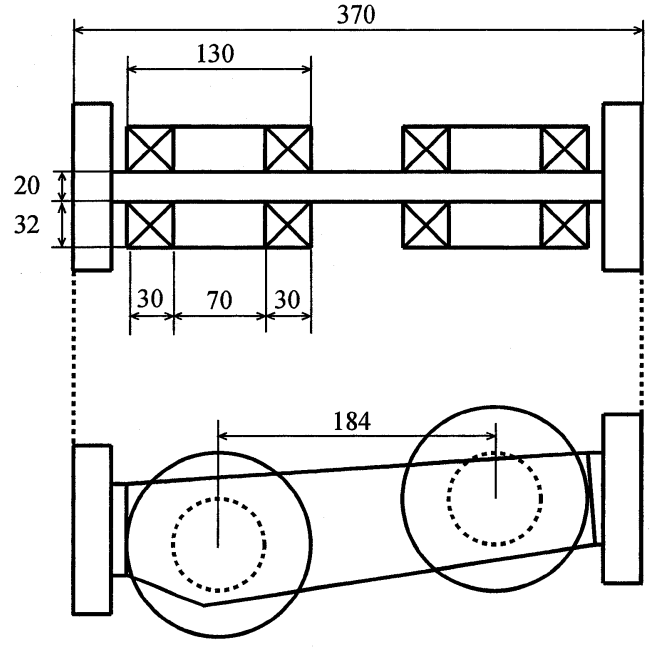

図 2 磁場偏向装置の模式図. 図中の数值は $\mathrm{mm}$ 単位である。

$\mathrm{mm}$ ，コイル間隔184 mm）を使用した.

初めに，この測定系に拉ける電子線の発散の様子を調 ベるために，電子線の軌道計算を行った，軌道計算で は，それぞれの視射角に対する試料位置における表面垂 直方向の電子線の幅，执よび開き角を求めた．電子線の 幅と開き角の変化の様子は同様な傾向を示したため, 図 3 には実際の初期条件に近い条件（入射電子線の幅 : $80 \mu \mathrm{m}$, 開き角 : $\left.0^{\circ}\right)$ に対する試料位置に打ける電子線 の幅を示す．この図から本試作装置で設計したコイル (均一な磁場領域が広い) では， $\theta=4^{\circ}$ 付近まで電子線は 収束し， $6^{\circ}$ 付近まで急速な発散が抑えられることが予想 された．実際，図 4 に示すように，本試作装置では $\theta=$ 


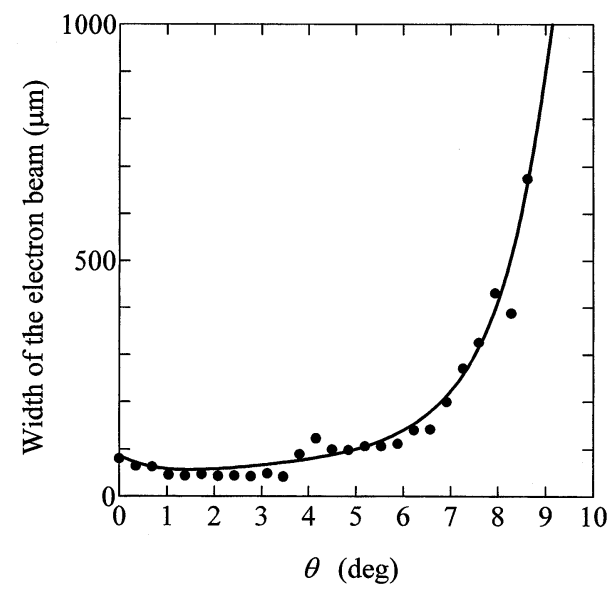

図 3 入射電子線の軌道計算. 視射角に対する電子 線の幅の変化を示す. 計算に用いたパラメー タとして, 電子線の幅, 開き角は, $80 \mu \mathrm{m}$, 拉よび 00 である.

$6^{\circ}$ 付近まで収束した電子線による鮮明な RHEED パタ ーンが得られている。

偏向装置に用いたコイルには，抵抗が $2.5 \Omega$, インダ クタンスが $2.5 \mathrm{mH}$ の中空コイルを使用した。 中空にし
た理由は, 磁場を高速に変化できるようコイルの時定数 を抑觉るためである.使用したコイルの時定数が約 1 $\mathrm{ms}$ であることから, 視射角变化を $0.05^{\circ}$ 刻みで行った場 合, $0.5 \sim 6^{\circ}$ の範囲を約 $0.1 \mathrm{~s}$ 間で行らことができる.

\subsection{RHEED 強度測定系}

強度測定装置は, SITカメラ（浜松ホトニクス(㮫） C2741-08)，カメラコントローラ（浜松ホトニクス(侏） $\mathrm{C} 2741 \mathrm{CCU})$, レーザービデオディスクレコーダ (SONY : LVR-3000AN), フレームメモリ（浜松ホトニ クス(侏：DVS-3000）によって構成されている. 強度測 定系のダイヤグラムを図 5 に示す。各視射角において， 蛍光スクリーンに映し出されたRHEED パターンは SITカメラによって撮影し，LVRに記録し，全録画終 了後に再生画像からフレームメモリを介して $\pm 0.5^{\circ}$ の視 射角範囲の回折スポットの積分強度を測定した. 測定時 に一番時間を取られる過程は LVR の録画過程であるの で，LVR の録画時間によって測定時間が制限されてい る. 録画時間は動画で $1 / 30 \mathrm{~s}$, 静止画で $1 / 6 \mathrm{~s}$ であり, 薄膜成長中の測定を考えるとできるだけ高速に測定を行 いたいが，動画録画方式では画質が悪く，測定強度の $\mathrm{S} / \mathrm{N}$ 比を上げるため, 現状では静止画録画方式による 約 $1 / 6 \mathrm{~s}$ で測定を行っている. したがって, 回折パター ンを視射角 $0.5 \sim 6^{\circ}$ まで $0.05^{\circ}$ 間隔で録画する（約 110 画
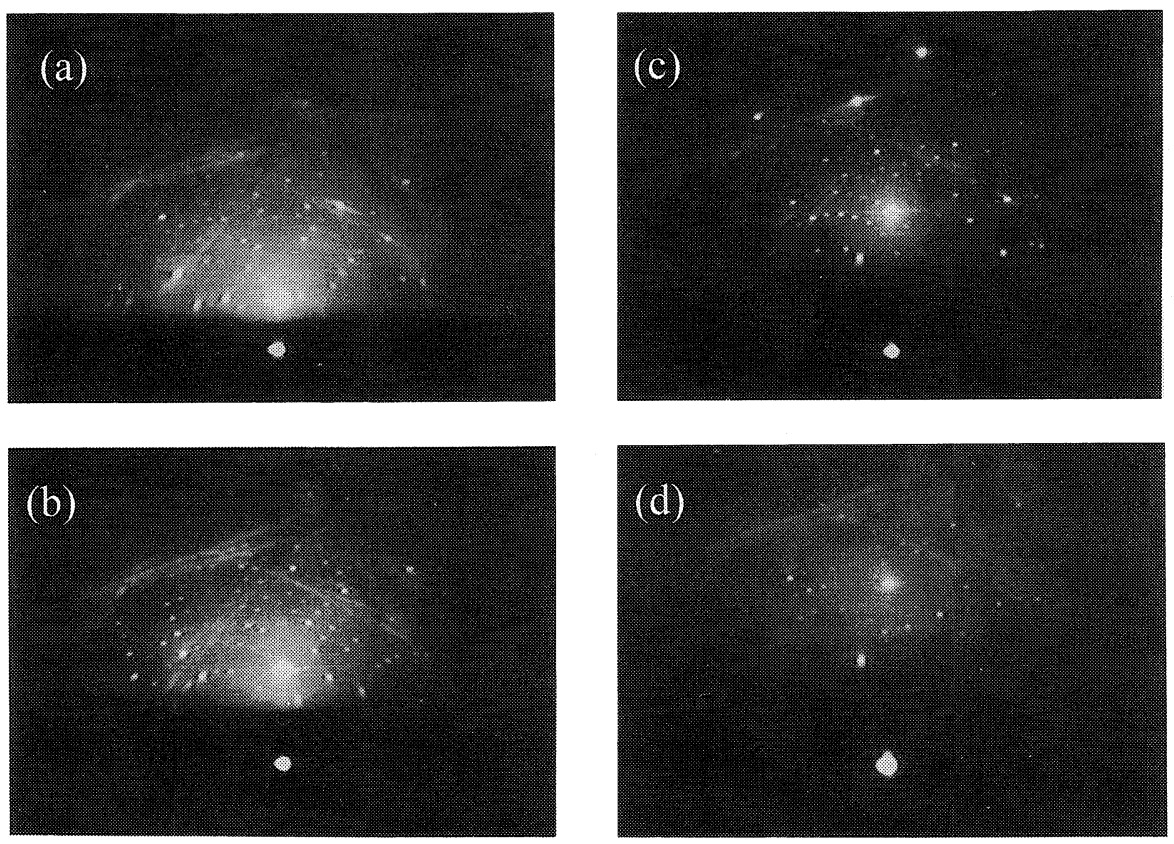

図 4 本装置で得られた RHEED パターン. (a) $\theta=1.2^{\circ}$, (b) $\theta=2.7^{\circ}$, (c) $\theta=4.0^{\circ}$, (d) $\theta=5.2^{\circ}$. 電子線の入射方 位は, [11 $\overline{2}]$ 方位から $7.5^{\circ}$ ずらした one-beam 条件. 


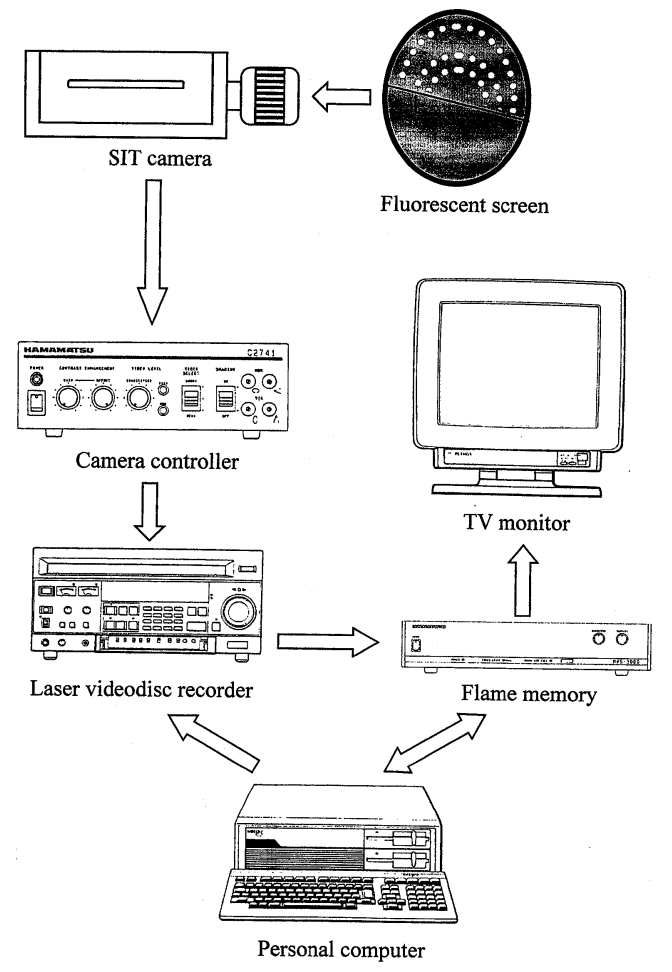

図 5 RHEED 強度測定系のダイヤグラム．

面）には, 約 $18 \mathrm{~s}$ の測定時間を要するが, 成長速度を遅 くすることで, この測定速度においてもサブモノレイヤ 一の成長を追うことが可能である.ただし現在, 画像処 理やデジタルムービー等, 録画技術が進歩しているの で, これからシステムを組まれる方は, 情報を集めれば 安くて高速なものが入手可能と思われる.

\section{3. 測定における初期の問題点と解決策}

\subsection{RHEED ロッキングカーブ測定条件と問題点}

試料には, 鏡面研磨された $\mathrm{N}$ 型 $\mathrm{Si}(111)$ ウェー（比 抵抗1.0-4.0 $\Omega \mathrm{cm}$ ，サイズ $\left.5 \times 25 \times 0.4 \mathrm{~mm}^{3}\right)$ を使用し

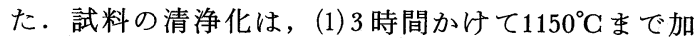
熱, (2)測定の前に $1200^{\circ} \mathrm{C} て ゙$ 数分フラッシング，の 2 段 階で行った．入射電子線の加速電圧は $10 \mathrm{kV}$ ，入射方位

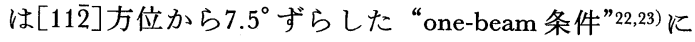
設定した.この入射方位では表面波の励起といった同時 反射が抑兄られ，原子位置が表面平行方向に平均化され た情報，つまり原子位置の表面に垂直な成分を知ること ができる。

実際に測定した初期の RHEED ロッキングカーブに は, 強度の急激な増減がランダムに見られた。これは電

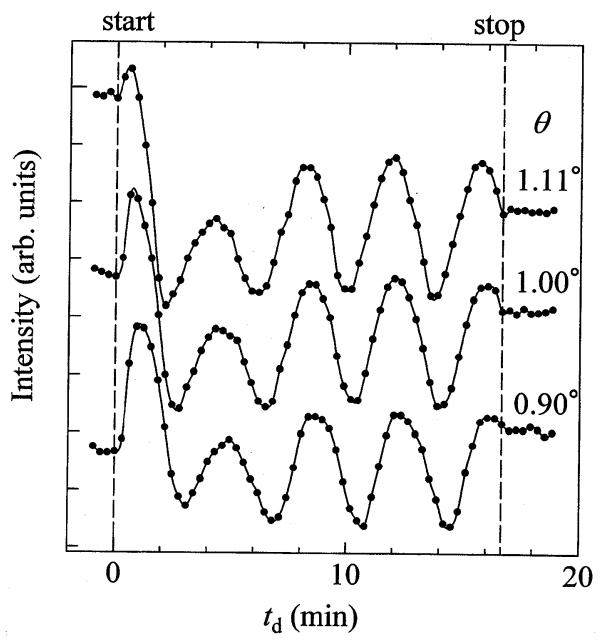

図 6 装置改良後の $\mathrm{Si} / \mathrm{Si}(111)$ 成長中の RHEED 強度振動.

子銃と試料の距離が長いためであり，振動の入る可能性 のある電子銃と偏向装置間に取り付けられている X-Y ステージへの固定の方法に問題があった. そこで，振動 が入らないよらにしっかりとした固定方法に変えた結 果, 強度の増減は大幅に軽減された。図 6 は改良後の RHEED 強度の時間変化，いわゆる RHEED 振動であ る. 固定方法の改良後, $\mathrm{S} / \mathrm{N}$ 比が一段と向上し，強度 の層成長に伴ら振動がはっきりと確認できるようになっ た。

\section{2 視射角の設定}

図 1 の 2 つ偏向コイル A と B の電流值は, 視射角 が0.5〜 6 の範囲を $0.05^{\circ}$ 刻みで変化するよらに設定する が，その設定方法はをずュイル B の電流を上げ，約 $0.05^{\circ}$ 刻みで電子線を下方に向ける。次に，コイル A の 電流值を増加・減少の 2 つのキーを用いて手入力で変化 させ, 試料に入射させる（1 Bit 当り $9.15 \mu \mathrm{A}$, 精度 : $\pm 27.5 \mu \mathrm{A})$. そして回折パターンが最も明るくなるとこ ろに合わせる方法を取っている。そ電流值は 110 組程 度になるが，それらのデータをコンピュータに記憶さ せ，繰り返し視射角を変化させるようにしている。

図 7(a)に，視射角に対するコイルの電流値の変化を 示す. 電流值は一見なめらかに変化しているように見觉 るが，一階微分したものでは図7(b)の黒丸のよらに， パターンを見て手入力で設定した電流値はなめらかに変 化していないことが分かる．本来この電流值はなめらか に変化すべきものなので, 図 7(a)の電流值のデータを $\theta$ の 3 次関数として最小自乗法によってフィットさせた 值をコイル A の実際の設定值とした. 3 次関数としたの 

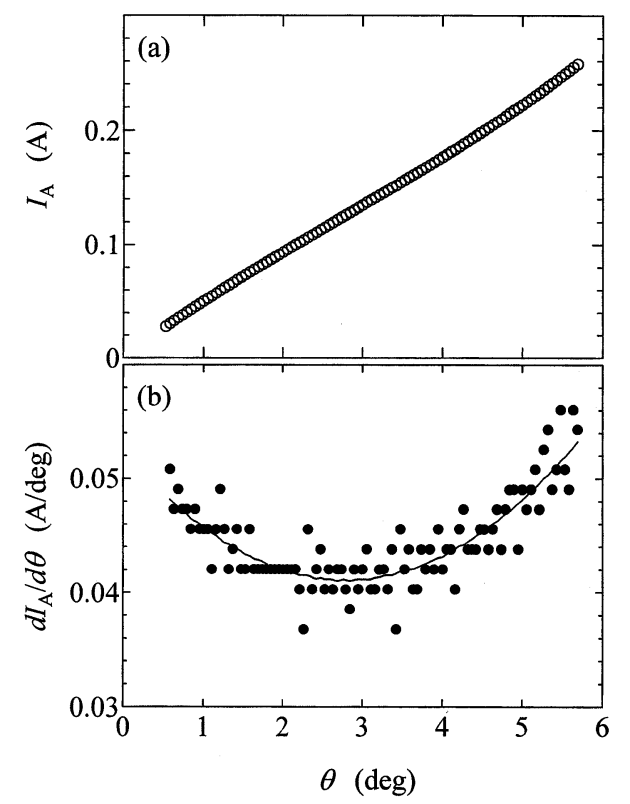

図 7 (a) 視射角に対する偏向コイル A の電流值 $\left(I_{\mathrm{A}}\right)$ 変化. (b) 視射角に対する偏向コイル $\mathrm{A}$ の電流値の微分 $\left(d I_{\mathrm{A}} / d \theta\right)$ の変化.

は, 図 7(b)の一階微分の変化が 2 次関数で近似でさる ためである. 図7(b)の実線は, 実際にフィットさせた 設定値を一階微分したものである.この補正は実際の測 定の $\mathrm{S} / \mathrm{N}$ 比を飛躍的に向上させた. 偏向コイルの初期 設定には，人間の目では判定できない微妙な誤差が含ま れてしまらが，データ処理を適切に行らことで補正する ことが可能となった.

\section{4. エピタキシャル成長への応用}

本装置の応用例として, 基板温度 $\left(T_{\mathrm{s}}\right)$ を $250^{\circ} \mathrm{C}^{19)}$ お よび $380^{\circ} \mathrm{C}^{20)}$ とした時の $\mathrm{Si} / \mathrm{Si}(111)$ エピタキシャル成長 測定について以下に述べる. 構造解析は, 動力学的回折 理論に基ついた RHEED 強度計算との比較によって行 なわれ, 成長中の拡散原子の情報や成長する層構造のダ イナミックな変化といった新たな知見が得られた.

\section{$4.1 T_{\mathrm{s}}=250^{\circ} \mathrm{C}$ の成長 ${ }^{19)}$}

図 8(a), (b) に, $T_{\mathrm{s}}=250^{\circ} \mathrm{C}$ とした時の成長中の RHEED ロッキングカーブを示す. 図の右側の番号は測 定の順番を表し, 番号 0 で示すカーブは基板から得られ たものである.この測定では, 蒸着量 $(d)$ が 1 bilayer （BL）に達するまでに12本のロッキングカーブを測定し ている、ここで用いた BL といら単位は, $\mathrm{Si}(111)$ 表面 が作る二重層の厚さ $0.31 \mathrm{~nm}$ で, この単位で層成長す
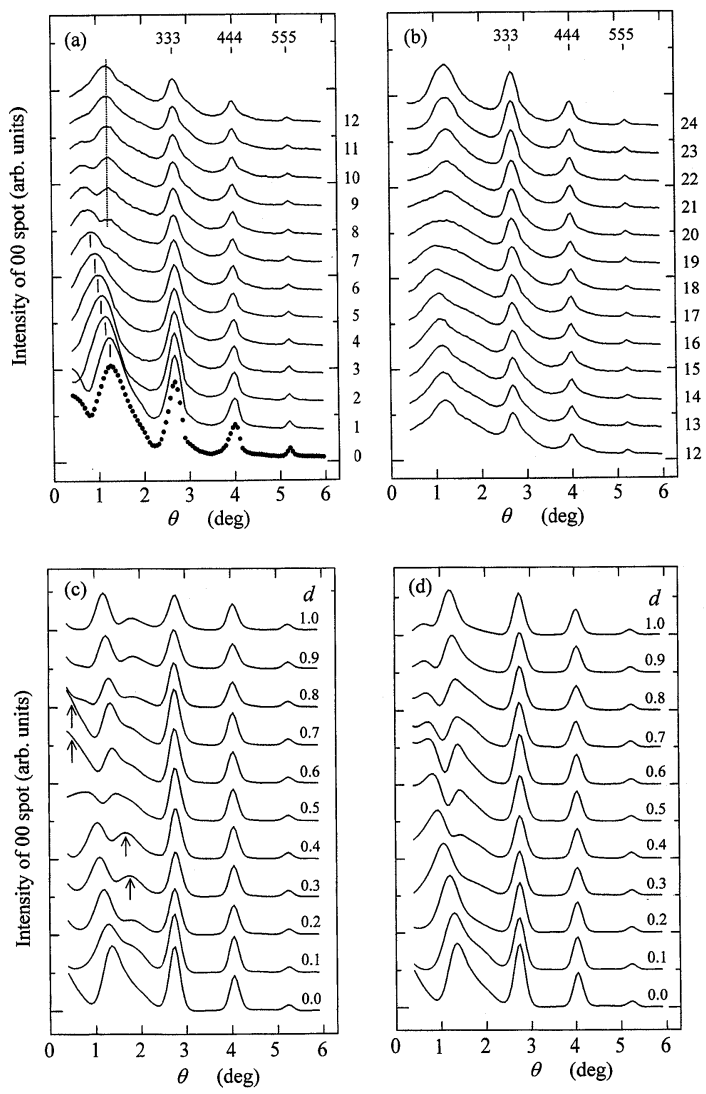

図 $8 \mathrm{Si} / \mathrm{Si}$ (111)成長中の RHEED ロッキングカー ブ $\left(T_{\mathrm{s}}=250^{\circ} \mathrm{C}\right.$. (a) $d=0.0 \sim 1.0 \mathrm{BL}$, (b) $d=$ 1.0〜2.0 BL. (c) STM 観察から得られた表面 モルフォロジーを用いて計算したカーブ.

(d) Si の 2 次元原子ガスを考慮に入れて計算 したカーブ19).

る. $T_{\mathrm{s}}=250^{\circ} \mathrm{C}$ における成長中の RHEED ロッキングカ ーブの特徵としては, (1) $\theta=1.3^{\circ}$ 付近のピークは, 蒸着 開始後, 強度を弱めながら徐々に低角側にシフトし, $d=1 \mathrm{BL}$ (カーブ12）に達するとほとんど見られなくな る, (2) $d=0.5 \mathrm{BL}$ (カーブ 6) に達すると再び $\theta=1.3^{\circ}$ 付 近にピークが出現し始める. その後 $1.3^{\circ}$ 付近のピークは 徐々に強度を強めていき, 一旦低角側 $\left(1.1^{\circ}\right)$ にシフト するが, 蒸着量が $2 \mathrm{BL}$ （カーブ24）に達すると, 再び 元の $1.3^{\circ}$ 付近に戻る. $d=2 \mathrm{BL}$ 以降, ロッキングカーブ は $1 \mathrm{BL}$ の周期で規則的に変化する, といったことが挙 ザられる.上記の $d<1 \mathrm{BL}$ の特徵的な振る舞いは, Horio と Ichimiya による動力学的計算結果にも見られ ている特徵であり, $\mathrm{Si}$ の島の核形成・成長に由来して いる24,25).

ところでこのときの成長モードは, STM 観察した結 
果から, $d=2 \mathrm{BL}$ 付近までは多層からなる 3 次元島成長 をしているが，それ以降の成長では層成長 (layer-bylayer 成長）飞変化することが分かっている11). そして， 成長中のロッキングカーブに括ける $d=2 \mathrm{BL}$ 以降の周 期的な変化は, 成長モードが layer-by-layer 成長に変化 したことに対応している。このような変化の他に考慮す べきこととして，成長中にはSTM では観察できない拡 散原子等が存在するはずである，以下では成長初期 $(d=1 \mathrm{BL}$ まで $)$ の変化に注目して解析した結果を述べ る.

我々は, 動力学的回折理論による RHEED 強度計算 を行い，実験から得られた RHEED ロッキングカーブ の解析を行った。計算は温度散漫散乱を考慮に入れ て ${ }^{21)}$, one-beam 条件に拈けるマルチスライス法22,23)を 用いて行った. 図 8(c) そ成長後の STM 観察から得られ たそれぞれの成長層の被覆率11をとのまま計算に導入し たロッキングカーブを示す．この図から，実験のカーブ に見られた前述の(1)と(2)の特徵は見ることがでさるが, 図中の矢印で示すような低角側の微妙な变化が実験結果 と対応していないことが分かる.

我々は, この実験と計算のカーブの相違が基板表面上 を動き回っている拡散原子の存在にあると考皃た，成長 中の基板表面には, 結晶に取り込まれずに拡散している 原子がいるはずである．したがって，成長後の STM 観 察で見られた成長層の原子の一部は成長中，表面上を拡 散していたと仮定できる. 図 8(d) は成長島の一部を 2 次元原子ガス状の拡散原子と置き換えて計算した口ッキ ングカーブである. 2 次元原子ガスは, 基板表面上のあ る高さを中心にガウス分布しているとして計算に取り入 れた。拡散原子を考慮に入れた場合, 眓8(c)の矢印で 示した実験結果との不一致がなくなり, 実験結果を良く 説明している. したがって成長中には基板表面上を拡散 している拡散原子を考慮する必要があることが分かっ た.

\section{$4.2 T_{\mathrm{s}}=380^{\circ} \mathrm{C}$ の成長 ${ }^{20)}$}

次に, 先ほどの $T_{\mathrm{s}}=250^{\circ} \mathrm{C}$ から少し温度を上げた $T_{\mathrm{s}}=$ $380^{\circ} \mathrm{C}$ の場合の成長について測定した。温度は $100^{\circ} \mathrm{C}$ 程 度しか違わないが，その基板上の成長は全く異なった成 長を示す. 図 9 (a), (b)の点線は, $T_{\mathrm{s}}=380^{\circ} \mathrm{C}$ とした時の 成長中の RHEED ロッキングカーブである．ここでは, $d=4 \mathrm{BL}$ まで連続的に測定したカーブから $0.5 \mathrm{BL}$ 扒きに 取り出してプロットした。図10は $\theta=2.5^{\circ}$ 付近までの RHEED 強度をロッキングカーブから取り出し, 蒸着時

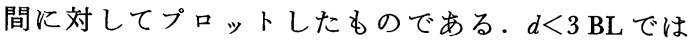

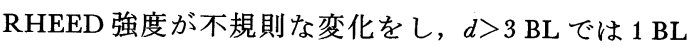
の周期で規則的な振動をしていることが見て取れる． $T_{\mathrm{s}}$
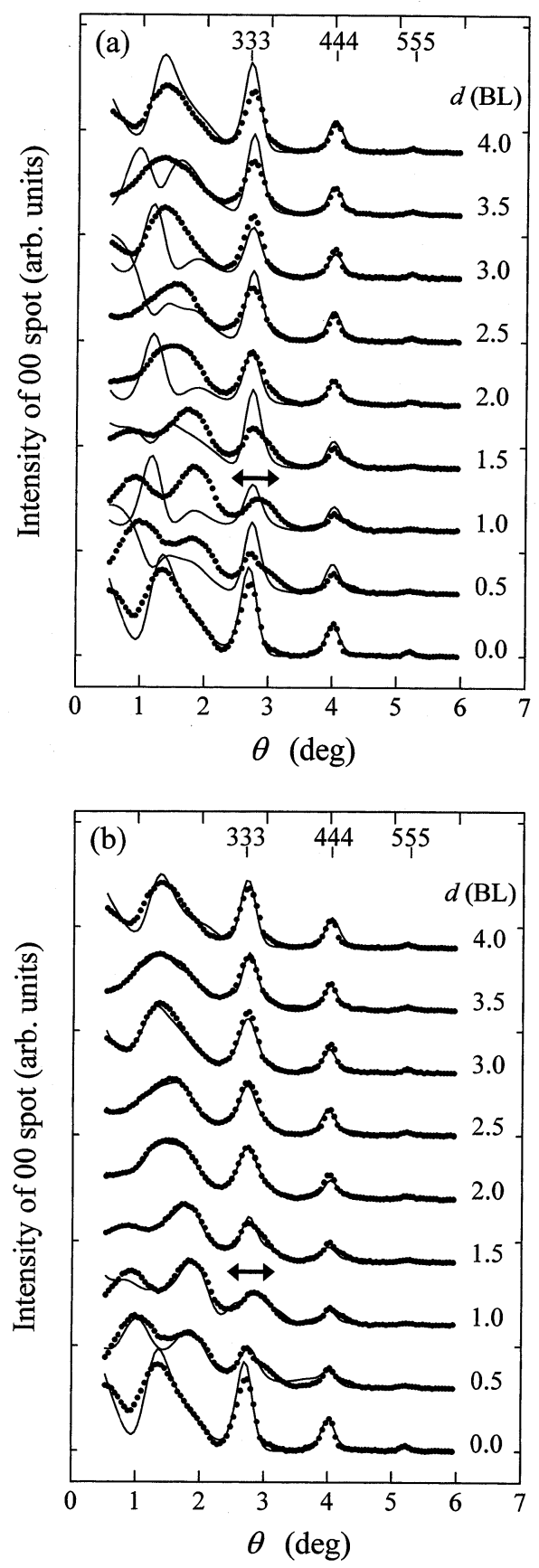

図 $9 \mathrm{Si} / \mathrm{Si}$ (111)成長中の RHEED ロッキングカー ブ $\left(T_{\mathrm{s}}=380^{\circ} \mathrm{C}\right)$. 点線は実験值, 実線は計算 值. (a)STM 観察から得られた表面モルフ オロジーを用いて計算したカーブ. (b)成長 層の原子位置を最適化して計算したカーブ20). 


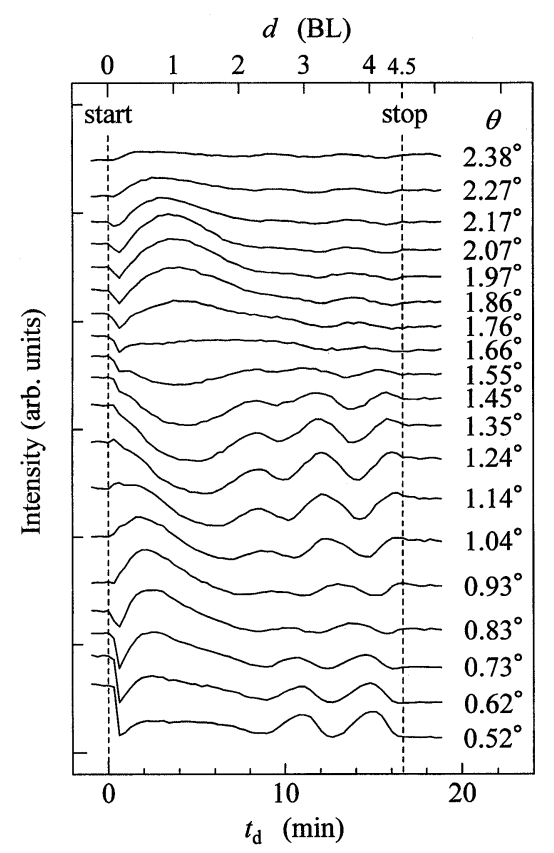

図10蒸着時間飞対する $\mathrm{Si} / \mathrm{Si}(111)$ 成長中の RHEED 強度変化 $\left(T_{\mathrm{s}}=380^{\circ} \mathrm{C}\right) . d<3 \mathrm{BL}$ で は, 3 次元島成長に対応した不規則振動が起 こり, $d>3 \mathrm{BL}$ では, layer-by-layer 成長に 対応した周期的な振動が起こる. 図の上に は蒸着時間に対応した蒸着量を示す20).

$=380^{\circ} \mathrm{C}$ の成長中のロッキングカーブに和いて最も顕著

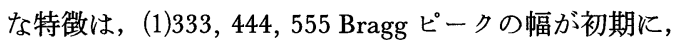
蒸着量の增加と共に広がり, 約 $d=3 \mathrm{BL}$ になると再び シャープになること, (2) $\theta=2.5^{\circ}$ 以下の強度分布が, $d=3 \mathrm{BL}$ までは周期的に変化しないことである（図10参 照).

以前の $\mathrm{STM}$ 観察から, $T_{\mathrm{s}}=380^{\circ} \mathrm{C}$ の場合, $d=3 \mathrm{BL}$ までは 3 次元島成長が起こり, その後 layer-by-layer 成 長に移行することが分かっている13). したがって, 前述 の $T_{\mathrm{s}}=250^{\circ} \mathrm{C}$ の場合と同㥞に, $d=3 \mathrm{BL}$ 以降の口ッキン グカーブの周期的な変化は, 成長モードが layer-by-layer 成長であることに対応している.すると， $d=3 \mathrm{BL}$ ま での非周期的な変化は， $T_{\mathrm{s}}=250^{\circ} \mathrm{C}$ の時と同様に, 拡散 原子によるではないかということが推測されるが，拡散 原子のみを考慮に入れて計算した場合では, Bragg ピー クの幅の広がりのよらな大きな変化は起こらず，以下で 示すよらに成長層の構造が成長中にダイナミックな変化 をしていることに起因していることが分かった。

図 8(c)の場合と同様に, STM 観察から得られた各層 の被覆率を用いて計算したロッキングカーブを図 $9(\mathrm{a})$

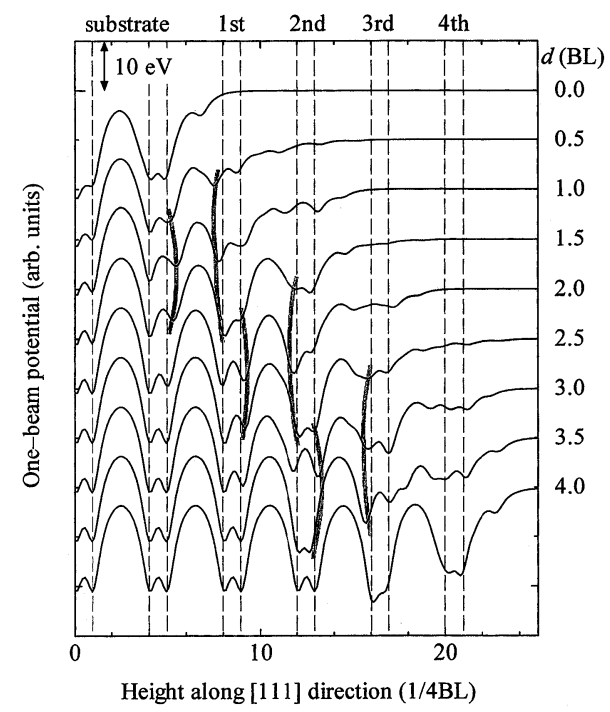

図11 $T_{\mathrm{s}}=380^{\circ} \mathrm{C}$ 亿拈ける $\mathrm{Si} / \mathrm{Si}(111)$ 成長中の結晶 ポテンシャルの変化. 3 次元島成長時には, 各成長層と下の層の間隔が系統的に変化し, 成長モードが layer-by-layer 成長に移行する と, その層間隔はバルクと同じ層間隔にな $ろ^{20)}$.

の実線で示す．特に低視射角側で実験值と計算值の一致 が悪く, 先ほど述べた Bragg ピークの幅の広がりが計 算には注とんど見られない，そこで，成長中の成長島の 構造を变化させ強度計算を行った. 図 9(b)の実線は成 長島の構造変化を取り入れて計算したカーブであり，実 験值と大変良く一致している. 図11はとの構造変化を見 るために，計算で用いた各々の成長段階に扣けるモデル 構造の結晶ポテンシャルである. 各層の成長が始まる と, 図中の太線が示すよらに, 成長層と下の層の間隔が バルクの層間隔より $0.024 \mathrm{~nm}$ 程度狭まることが各層で 見られる，その後 layer-by-layer 成長に移行すると，そ の層間隔はバルクの層間隔から变化しないことが分かっ た. したがって, $T_{\mathrm{s}}=380^{\circ} \mathrm{C}$ の場合, $250^{\circ} \mathrm{C}$ に比へ成長層 の構造が成長中にダイナミックな変化をしていることが 分かった。このように成長中の RHEED ロッキングカ ーブを測定することで, STM 観察では得られない表面 層のダイナミックな変化を解明できる.

\section{5. まと め}

結晶成長のメカニズムを解明するためには，成長中の その場観察が必要不可欠である。本稿では, RHEED口 ッキングカーブ測定が成長中の構造解析に適用でき，有 用な手法であることを示した。ここで例に挙げた $\mathrm{Si} /$ 
$\mathrm{Si}$ (111)系の成長中のように, STM では知ることのでき ない基板表面上を拡散している 2 次元 $\mathrm{Si}$ 原子ガスの存 在や, 成長層のダイナミックな構造変化に対して威力を 発揮することが分かった，したがって，本装置と STM 装置を併用することが，結晶成長のメカニズムをより広 く解明できる方法であると言える.

さらに，本装置を用いることによって，成長中と STM で観察されるような構造緩和後の表面構造をつな ぐ，構造緩和過程などの情報も得ることが可能であり， 今後, 表面構造解析に更なる応用が期待できると考えて いる.

\section{謝辞}

偏向系の製作にあたり協力を頂いた柳田博司氏（日本 真空技術(侏)）に感謝致します．ここに紹介した研究は,

一部, (財)高橋産業経済研究財団および横浜市立大学研究 奨励交付金の助成により進められたことを報告致しま †.

\section{[文献}

1) B. S. Swartzentruber: Phys. Rev. Lett., 76 (1996) 459.

2) J. J. Harris, B. A. Joyce and P. J. Dobson: Surf. Sci., 103 (1981) L90.

3) T. Sakamoto, N. J. Kawai, T. Nakagawa, K. Ohta and T. Kojima: Appl. Phys. Lett., 47 (1985) 617.

4) J. Aarts and P. K. Larsen: Surf. Sci., 188 (1987) 391.

5) M. Ichikawa and T. Doi: Appl. Phys. Lett., 50 (1987) 1141.

6) H. Nakahara and A. Ichimiya: Surf. Sci., 241 (1991) 124.
7) P. A. Maksym and J. L. Beeby: Surf. Sci., 110 (1981) 423.

8) A. Ichimiya: Jpn. J. Appl. Phys., 22 (1983) 176; 24 (1985) 1365.

9) T. C. Zhao, H. C. Poon and S. Y. Tong: Phys. Rev., B38 (1988) 1172.

10) G. Meyer-Ehmsen: Surf. Sci., 219 (1989) 177.

11) Y. Shigeta, J. Endo and K. Maki: Phys. Rev., B51 (1995) 2021.

12) Y. Shigeta, J. Endo and K. Maki: J. Cryst. Growth, 166 (1996) 617.

13) Y. Shigeta: Surf. Rev. \& Lett., 5 (1998) 865.

14) Y. Shigeta, H. Fujino and K. Maki: J. Appl. Phys., 86 (1999) 881.

15) Y. Horio and A. Ichimiya: Surf. Sci., 133 (1983) 393.

16) T. Hanada, S. Ino and H. Daimon: Surf. Sci., 313 (1994) 143.

17) P. I. Cohen, P. R. Pukite, J. M. Van Hove and C. S. Lent: J. Vac. Sci. Technol., A4 (1986) 1251.

18) P. K. Larsen, P. J. Dobson, J. H. Neave, B. A. Joyce, B. Bölger and J. Zhang: Surf. Sci., 169 (1986) 176.

19) Y. Shigeta, Y. Fukaya, H. Mitsui and K. Nakamura: Surf. Sci., 402-404 (1998) 313.

20) Y. Fukaya, Y. Shigeta and K. Maki: Phys. Rev., B61 (2000) in press.

21) K. Yamaguchi, H. Mitsui and Y. Shigeta: J. Vac. Sci. Technol., A15 (1997) 2569; A17 (1999) 3530.

22) A. Ichimiya: Surf. Sci., 192 (1987) L893.

23) A. Ichimiya: The Structure of Surfaces III, Springer Series in Surface Sciences. Vol. 24 (Springer, Berlin, 1991) p. 162.

24) Y. Horio and A. Ichimiya: Surf. Sci., 298 (1993) 261.

25) Y. Horio and A. Ichimiya: Ultramicroscopy, 55 (1994) 321. 